\title{
Shear Strength of Lightly Reinforced T-Beams in Negative Bending
}

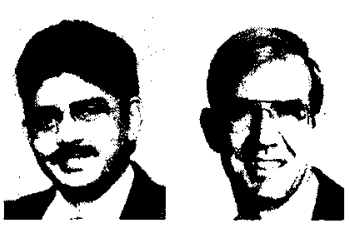

by Carlos P. Rodrigues and David Darwin
Nine restrained $T$-beams were tested in a study of the negative moment region shear strength of lightly reinforced concrete T-beams. Variables included the longitudinal reinforcement ratio $\rho_{\mathrm{s}}(0.47$ percent and 0.70 percent) and the nominal stirrup strength 10 to 84 psi 10 to $0.60 \mathrm{MPaJ})$. The test results are compared with the shear provisions of "Building Code Requirements for Reinforced Concrete (ACI 318-83)."

Both the concrete and stirrup contributions to shear strength are lower in negative than in positive moment regions. In both moment regions, the cracking shear is lower and the stirrup contribution is higher than predicted by $A C I$ 318. Current provisions are conservative for positive moment regions of beams with $\rho_{w} 10 \geqslant 0.5$ percent. The provisions are also conservative for negative moment regions in which the factored shear $\mathrm{V}_{\mathrm{u}}$ is less than or equal to the design shear strength of the concrete $\phi \mathrm{V}_{\mathrm{c}}$. However, ACI 318 appears to be unconservative for negative moment regions of beams with $\rho_{\mathrm{u}} \leqslant 0.7$ percent and $\mathrm{V}_{\mathrm{u}}$ $>\phi \mathrm{V}_{\mathrm{w}}$. The provisions may also be unconservative for joists with $\rho_{\mathrm{w}} \leqslant 1$ percent and $\phi \mathrm{V}_{\mathrm{c}} / 2 \leqslant \mathrm{~V}_{\mathrm{u}} \leqslant \phi \mathrm{V}_{\mathrm{s}}$.

Keywords: beams (supports); cracking (fracturing); diagonal tension; flexural strength; loads (forces): reinforced concrete; reinforcing steels; research; shear strength; stirrups; structural engineering; T-beams; web reinforcement.

The effect of the longitudinal reinforcement ratio on the shear cracking load of reinforced concrete beams is not accurately incorporated in the design requirements of the ACI Building Code, ACI 318-83.' While the shear cracking loads in ACI 318-83 are conservative for beams having longitudinal reinforcement ratios $\rho_{w}$ greater than 1 percent, they are unconservative for beams with $\rho_{w}$ less than 1 percent. ${ }^{2-9}$ In spite of this, the overall shear provisions have appeared to be satisfactory, since the Building Code underestimates the contribution of web reinforcement ${ }^{9-11}$ and requires its use in beams with shears greater than one-half of the predicted cracking shear $\left(V_{u} \geqslant \phi V_{c} / 2\right)$.

Most of what is known about shear strength is based on tests of simply supported beams subjected to positive bending, even though most reinforced concrete beams are continuous. This tacitly assumes that continuity has no effect on shear strength. However, continuous beams behave differently. Most notably, the flanges crack in negative moment regions, giving a smaller effective section to carry shear than is available in positive moment regions. The flexural steel in the negative moment regions usually consists of top-cast bars, which have a lower bond strength than the bottom-cast bars in positive moment regions. This results in both wider flexural cracks and wider flexure-shear cracks in regions of negative moment. There is specific experimental evidence that the negative moment region has a lower shear strength than the positive moment region."

Finally, as suggested by Ferguson, ${ }^{12}$ continuous beams may have a reduced shear strength due to inclined flexure-shear cracks which result in an increased effective shear-span and a reduced concrete contribution to shear capacity.

Differences in the behavior of continuous and simple-span beams, along with the reduced concrete shear capacity in beams with $\rho_{w}<1$ percent, makes the shear strength of continuous reinforced concrete beams with low values of longitudinal reinforcement a particular concern.

This paper presents the results of a limited experimental study of the negative moment region shear strength of lightly reinforced concrete T-beams. The primary variables in this investigation were the longitudinal reinforcement ratio and the nominal stirrup strength. The test results, along with test results for lightly reinforced simple-span beams, ${ }^{9}$ are analyzed and compared with the ACI Building Code provisions.' The details of the investigation are presented in Reference 13.

\section{RESEARCH SIGNIFICANCE}

The current research is significant because it represents the first test data on the negative moment region shear strength of beams with low values of both flexural and shear reinforcement. These results are of par-

Received Feb. 19, 1986, and reviewed under Institute publication policies. Copyright (C) 1987. American Concrete Institute. All rights reserved, including the making of copies unless permission is obtained from the copyright proprietors. Pertinent discussion will be published in the Nov.-Dec. 1987 ACI StruCtural Journal if received by July $1,1987$. 
ACI member Carlos P. Rodrigues is a facility engineer with Pan Am World Services, Inc., NASA/NSTL, Miss. He received his BE in civil engineering from Karnatak University, India, and the MSCE degree from the University of Kansas.

David Darwin, FACI, is Professor of Civil Engineering and Director of the Structural Engineering and Materials Laboratory at the University of Kansas. He is a member of the Technical Activities Committee and Past-President of the Kansas Chapter of ACI. He is also a member and past-chairman of ACI Committee 224, Cracking, and is a member of ACI Committees 408, Bond and Development of Reinforcement; and 446. Fracture Mechanics; ACI-ASCE Committee 445, Shear and Torsion; and the Concrete Materials Research Council. Darwin received the ASCE Walter L. Huber Civil Engineering Research Prize in 1985 and the ACI Delmar L. Bloem Distinguished Service Award in 1986

ticular interest because they show that the shear provisions of ACI 318 may be significantly unconservative in negative moment regions of beams with $\rho_{w}$ less than 0.7 percent and factored shears $V_{u}$ greater than the design shear capacity of the concrete $\phi V_{c}$. The study also suggests that the shear provisions may be unconservative for joists with $\rho_{w}$ less than 1 percent and $\phi V_{c} / 2 \leqslant V_{u}$ $\leqslant \phi V_{c}$.

\section{Test specimens}

\section{EXPERIMENTAL INVESTIGATION}

Nine restrained reinforced $\mathrm{T}$-beams were tested to failure. The details and dimensions of the beams are shown in Fig. 1 and Table 1 . The flange width $b$ and thickness $h_{f}$ were $24 \mathrm{in}$. and $4 \mathrm{in}$. $(610 \mathrm{~mm}$ and 102 $\mathrm{mm}$ ), respectively. The web width $b_{w}$ was $7 \frac{1}{2}$ in. (191

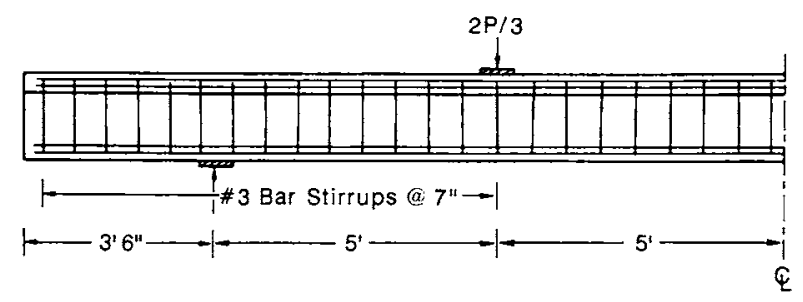

Positive Moment Region
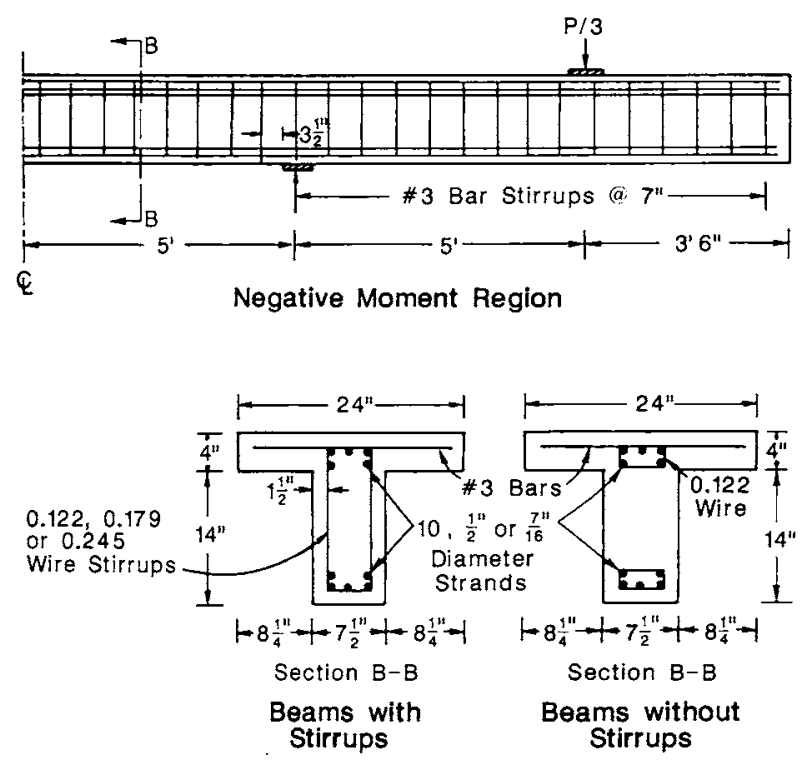

Fig. I-Beam details $(1 \mathrm{in} .=25.4 \mathrm{~mm})$ $\mathrm{mm})$, and the total beam depth was 18 in. $(457 \mathrm{~mm})$. The beams had a $15-\mathrm{ft}(4.57-\mathrm{m})$ span, with a 5 -ft $(1.52-$ $\mathrm{m})$ cantilever on one side. Extensions of $3 \mathrm{l} / 2-\mathrm{ft}(1.07-\mathrm{m})$ were added on each end of the beams to increase the embedment and prevent slippage of the flexural steel. The shear-span-to-depth ratio for the beams was approximately equal to 4 , with the shear-span extending from the point of inflection to the maximum positive or negative moment sections. The moment and shear diagrams for the applied loads are shown in Fig. 2.

Two series, D and E, were tested, with longitudinal reinforcement ratios $\rho_{w}$ (both top and bottom) equal to 0.70 percent and 0.47 percent, respectively. The longitudinal reinforcement consisted of non-prestressed, prestressing strands.

Strands were used to provide a low longitudinal reinforcement ratio and at the same time insure flexural safety. The specimens correspond to continuous beams with low values of $\rho_{w}$ that have undergone local flexural failure but which remain intact due to moment redistribution; although the local flexural strength has been exceeded, the capacity is governed by the shear strength.

Web reinforcement consisted of smooth low-carbon wires. The nominal shear stress provided by the stirrups $v_{s}=\rho_{v} f_{v y}$ ranged from 0 to $84 \mathrm{psi}(0$ to $0.60 \mathrm{MPa})$ $\left(\rho_{*}=\right.$ shear reinforcement ratio $=A_{i} / b_{w} s$ in which $A_{v}$. $=$ stirrup area, $s=$ stirrup spacing, and $f_{v y}=$ stirrup yield strength). The wires were used in the test region, which consisted of one positive and one negative shearspan. Heavy web reinforcement was provided elsewhere.

Table 1 - Beam properties and test results

\begin{tabular}{|c|c|c|c|c|c|c|c|c|c|}
\hline Beam & $\begin{array}{l}d, \\
\text { in. }\end{array}$ & $\begin{array}{l}b_{w}, \\
\text { in. }\end{array}$ & $\begin{array}{c}\rho_{w}=\frac{A_{s}}{b_{w} d} \\
\text { percent }\end{array}$ & $\begin{array}{c}\rho_{p} f_{\mathrm{v},}, \\
\mathrm{psi} \\
\end{array}$ & $\left\{\begin{array}{c}f_{t^{\prime}}^{*} \\
\text { psi }\end{array}\right.$ & $\begin{array}{c}f_{r}^{\prime}, \\
\text { psi } \\
\end{array}$ & $a / d$ & $\begin{array}{l}v_{s}, \\
\text { psi }\end{array}$ & $\begin{array}{l}v_{n}, \\
\text { psi } \\
\end{array}$ \\
\hline \multicolumn{10}{|c|}{ Positive moment region } \\
\hline $\begin{array}{l}\text { D-80(1) } \\
\text { D-80(2) } \\
\text { D-40 } \\
\text { D-20 } \\
\text { D-0 } \\
\text { E-80 } \\
\text { E-40 } \\
\text { E-20 } \\
\text { E-0 }\end{array}$ & $\begin{array}{l}15.44 \\
14.87 \\
14.69 \\
14.58 \\
14.69 \\
14.78 \\
15.14 \\
15.46 \\
15.43\end{array}$ & $\begin{array}{l}7.58 \\
7.52 \\
7.50 \\
7.52 \\
7.53 \\
7.51 \\
7.50 \\
7.51 \\
7.50\end{array}$ & $\begin{array}{l}0.69 \\
0.72 \\
0.73 \\
0.73 \\
0.73 \\
0.49 \\
0.48 \\
0.47 \\
0.47\end{array}$ & $\begin{array}{r}82.9 \\
73.0 \\
37.0 \\
21.6 \\
0.0 \\
73.5 \\
36.8 \\
22.2 \\
0.0\end{array}$ & $\begin{array}{l}5380 \\
4070 \\
4200 \\
4290 \\
4540 \\
4010 \\
4550 \\
4210 \\
4500\end{array}$ & $\begin{array}{l}445 \\
435 \\
500 \\
515 \\
440 \\
500 \\
560 \\
475 \\
565\end{array}$ & $\begin{array}{l}3.89 \\
4.03 \\
4.08 \\
4.11 \\
4.08 \\
4.06 \\
3.96 \\
3.88 \\
3.89\end{array}$ & $\begin{array}{r}103 \\
139 \\
100 \\
145 \\
114 \\
114 \\
127 \\
89 \\
114\end{array}$ & $\begin{array}{l}238 \\
- \\
- \\
- \\
\overline{181} \\
\overline{133}\end{array}$ \\
\hline \multicolumn{10}{|c|}{ Negative moment region } \\
\hline $\begin{array}{l}\text { D-80(1) } \\
\text { D-80(2) } \\
\text { D-40 } \\
\text { D-20 } \\
\text { D-0 } \\
\text { E-80 } \\
\text { E-40 } \\
\text { E-20 } \\
\text { E-0 }\end{array}$ & $\begin{array}{l}15.18 \\
15.32 \\
15.39 \\
15.21 \\
15.76 \\
15.04 \\
15.54 \\
15.42 \\
16.13\end{array}$ & $\begin{array}{l}7.52 \\
7.51 \\
7.52 \\
7.51 \\
7.51 \\
7.51 \\
7.50 \\
7.50 \\
7.52\end{array}$ & $\begin{array}{l}0.71 \\
0.70 \\
0.70 \\
0.71 \\
0.68 \\
0.48 \\
0.46 \\
0.47 \\
0.45\end{array}$ & $\begin{array}{r}83.6 \\
73.1 \\
37.0 \\
21.6 \\
0.0 \\
73.5 \\
36.8 \\
22.2 \\
0.0\end{array}$ & $\begin{array}{l}5380 \\
4070 \\
4200 \\
4290 \\
4540 \\
4010 \\
4550 \\
4210 \\
4500\end{array}$ & $\begin{array}{l}445 \\
435 \\
500 \\
515 \\
440 \\
500 \\
560 \\
475 \\
565\end{array}$ & $\begin{array}{l}3.95 \\
3.92 \\
3.90 \\
3.94 \\
3.81 \\
3.99 \\
3.86 \\
3.89 \\
3.72\end{array}$ & $\begin{array}{c}101 \\
100 \\
111 \\
111 \\
119 \\
64 \\
\frac{-}{93} \\
68\end{array}$ & $\begin{array}{l}-\overline{200} \\
146 \\
148 \\
138 \\
152 \\
- \\
127 \\
-\end{array}$ \\
\hline \multicolumn{10}{|c|}{ 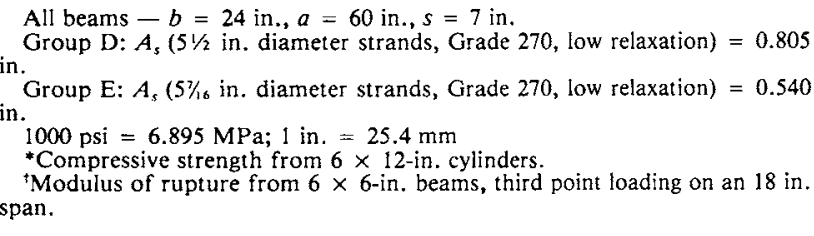 } \\
\hline
\end{tabular}

ACI Structural Journal / January-February 1987 


\section{Material properties}

Concrete - Type I portland cement and $3 / 4$ in. (19 $\mathrm{mm})$ maximum size coarse aggregate were used. Airentrained concrete was supplied by a ready-mix plant. Compressive strengths and moduli of rupture are summarized in Table 1.

Steel - ASTM A 416 Grade $270(1860 \mathrm{MPa}), 1 / 2 \mathrm{in}$. (13 mm) diameter seven-wire low-relaxation strands and Grade 250 (1724 MPa), $7 / 16$ in. (11 mm) diameter sevenwire low-relaxation strands were used as the flexural steel in Series D and E, respectively. The strands were exposed to the weather and allowed to rust to improve bond and prevent slip during the tests. ASTM A 615 Grade $60(414 \mathrm{MPa}) \# 3(9.5 \mathrm{~mm})$ deformed billet steel bars were used as transverse flange reinforcement and as web reinforcement outside the test region. The lowcarbon smooth wires used as stirrups within the test region had diameters of $0.122,0.179$, and 0.245 in. (3.10, 4.55 , and $6.22 \mathrm{~mm}$ ) for beams with $\rho_{v} f_{i y}$ of approximately 20,40 , and 80 psi $(0.15,0.30$, and $0.60 \mathrm{MPa})$, respectively. Information on the reinforcing steel is summarized in Table 1.

\section{Test procedure}

Loads were applied to the beams at two points, using a longitudinal loading beam (Fig. 3), to develop equal maximum positive and negative moments and provide a constant value of applied shear throughout the length of the beam (Fig. 2).

The deflection at the load points was recorded. Stirrup strains were obtained with strain gages attached at midheight, while changes in the overall depth of the beam due to diagonal tension cracking were measured using dial gages attached to specially designed shear cracking frames. ${ }^{9}$

The beams were loaded incrementally until failure was obtained. Cracks were marked for each load increment. About $75 \mathrm{~min}$ were required for a test.

\section{Results and observations}

As the beams were subjected to increasing loads, flexural cracks were observed at or near the maximum moment sections. As the load increased, these cracks extended vertically to about the centroid of the uncracked section. Typical crack patterns are shown in Fig. 4. The cracks curved towards the point of applied load in the positive shear-span and towards the cantilever support in the negative shear-span.

The failure mode for all beams was diagonal tension. Six failed in the negative shear-span and three in the positive shear-span. In the positive moment region (Fig. 5), the critical shear crack appeared after the cut across earlier shear cracks, while in the negative moment region (Fig. 6), one of the initial shear cracks grew to become the critical shear crack.

In the negative shear-span, when the beams approached failure, a secondary crack developed and propagated along the intersection of the web and flange, usually cutting across two stirrups for the beams in Series D and one stirrup in Series E, as the bottom end of the critical shear crack neared the support. The bottom end of the critical shear crack extended until it reached the support.

The number and width of cracks depended on the amount of flexural reinforcement. The beams in Series $D$ exhibited a greater number of cracks of narrower width than the beams in the more lightly reinforced Series E. No shear cracks were observed at or near the point of inflection.

The negative moment regions had fewer, more widely spaced cracks than the positive moment regions (Fig. 4). This difference in the crack patterns is in all likelihood due to the fact that the top-cast flexural reinforcement, which controls flexural cracking in the negative moment regions, has a lower bond strength than the bottom-cast flexural reinforcement, which controls flexural cracking in the positive moment regions. This difference in bond strength is commonly referred to as the top-bar effect.
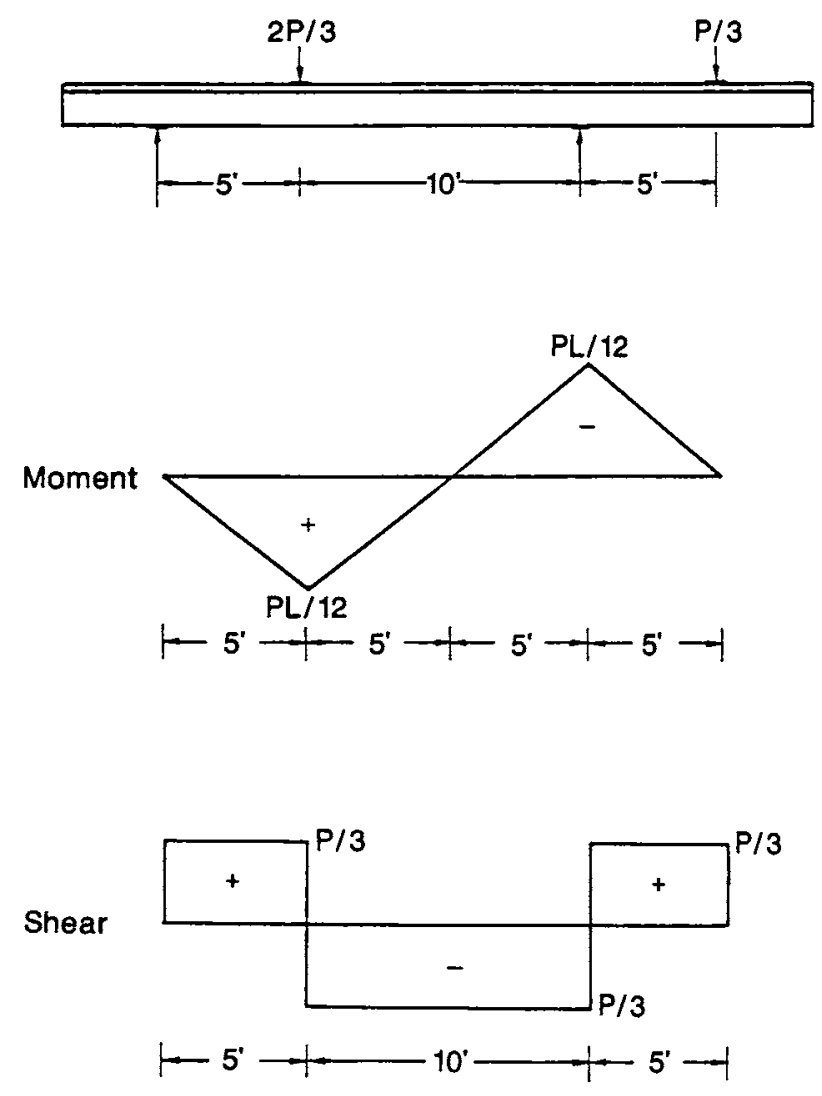

Fig. 2-Moment and shear diagrams due to loadings (1 $f t=305 \mathrm{~mm})$

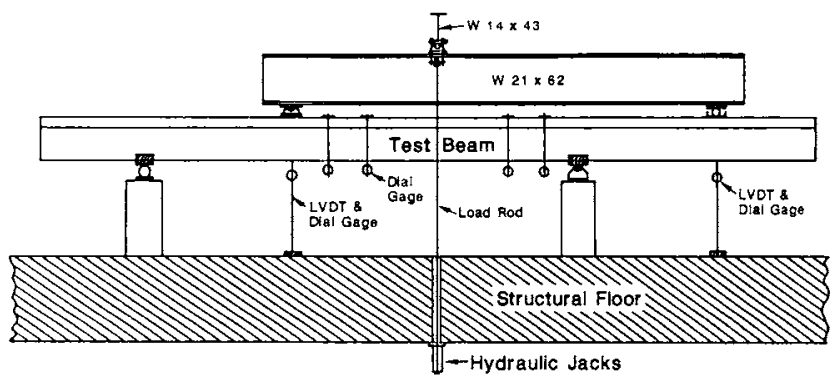

Fig. 3-Test setup 


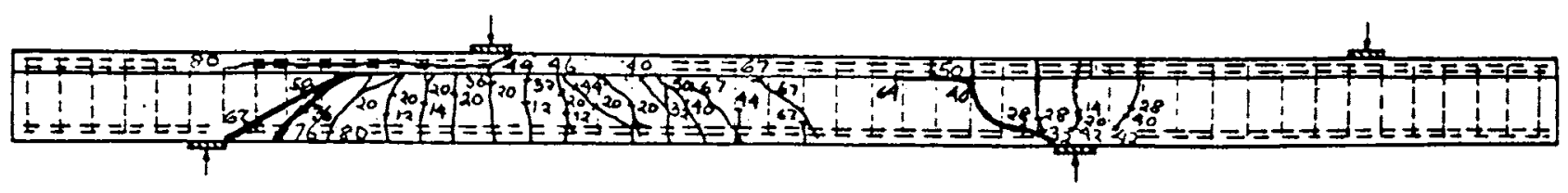

Beam D-80(1) $\left(\rho_{w}=0.69 \%, \rho_{v} f_{v y}=82.9\right.$ psi)

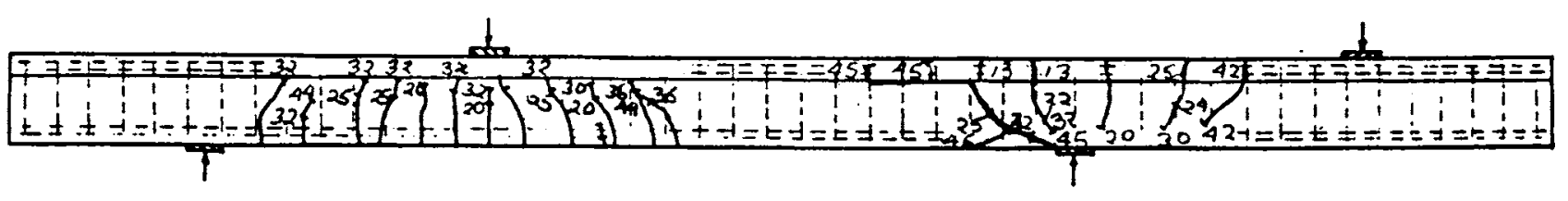

Beam D-40( $\left.\rho_{w}=0.70 \%, \rho_{v} f_{v y}=37.0 p s i\right)$

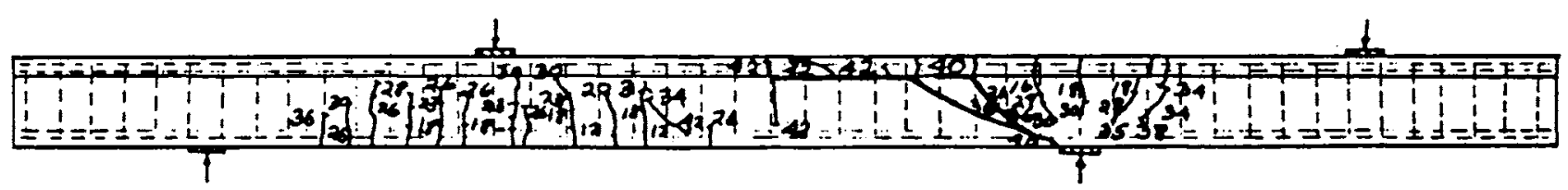

Beam D- $0\left(\rho_{w}=0.68 \%, \rho_{v} f_{v y}=0.0 \mathrm{psi}\right)$

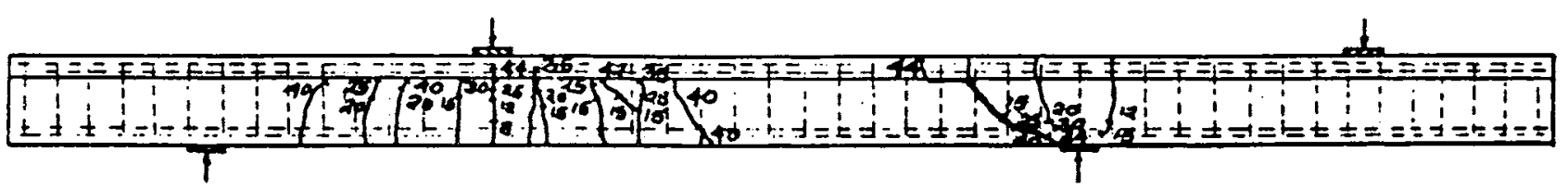

Beam E-80( $\left.\rho_{w}=0.48 \%, \rho_{v} f_{v y}=73.5 p s i\right)$

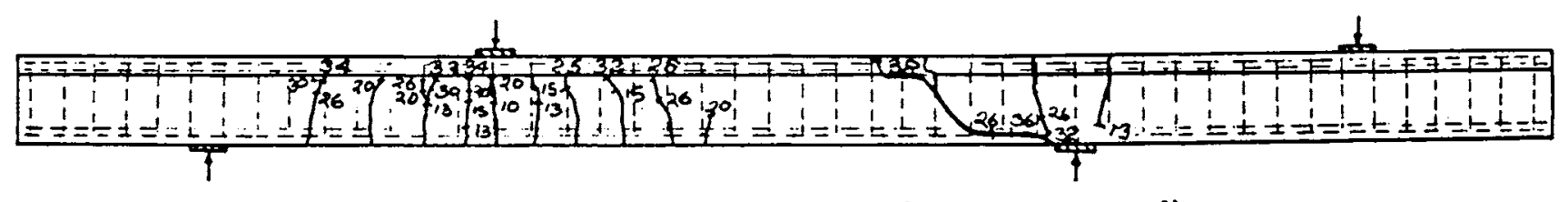

Beam E-20( $\left.\rho_{w}=0.47 \%, \rho_{v} f_{v y}=22.2 p s i\right)$

Fig. 4-Typical crack patterns

Stirrups intersected by a critical diagonal tension crack yielded prior to failure.

A summary of the shear cracking stresses (based on crack patterns) along with the nominal shear stresses is given in Table 1.

\section{EVALUATION OF EXPERIMENTAL RESULTS Shear cracking}

For Series $\mathrm{D}$ and $\mathrm{E}$, the shear cracking stress $v_{c}$ is on the average 18 percent greater in the positive moment region than the negative moment region (Table 1 ). This should be expected since a T-beam is effectively a rectangular beam in the negative moment region. In the positive moment region, however, the compressive stresses are distributed over the area of the flange, which affects the total stress distribution. It is also likely that the lower bond strength of the top-cast reinforcement contributes to the lower relative shear strength of the negative moment region. The higher value of $v_{c}$ in positive bending agrees with the results of Placas and Regan, ${ }^{6}$ who found that beams with 12 in. or wider flanges had about 20 percent more shear strength than rectangular beams.

For beams without web reinforcement, the cracking shear is given by the following equation in ACI $318-83^{!}$.

$$
\begin{aligned}
v_{c} & =\left(1.9 \sqrt{f_{c}^{\prime}}+2500 \rho_{w} V_{u} d / M_{u}\right) b_{w} d \\
& \leqslant 3.5 \sqrt{f_{c}^{\prime}} b_{w} d
\end{aligned}
$$

in which $f_{c}^{\prime}=$ compressive strength of concrete, psi; $V_{u}$ = factored shear force at section; $M_{u}=$ factored bending moment at section; and $d=$ effective depth.

Or more conservatively

$$
V_{c}=2 \sqrt{f_{c}^{\prime}} b_{w} d
$$

In terms of shear stress $v_{c}$ Eq. (1a) and (2a) can be rewritten as

ACI Structural Journal / January-February 1987 


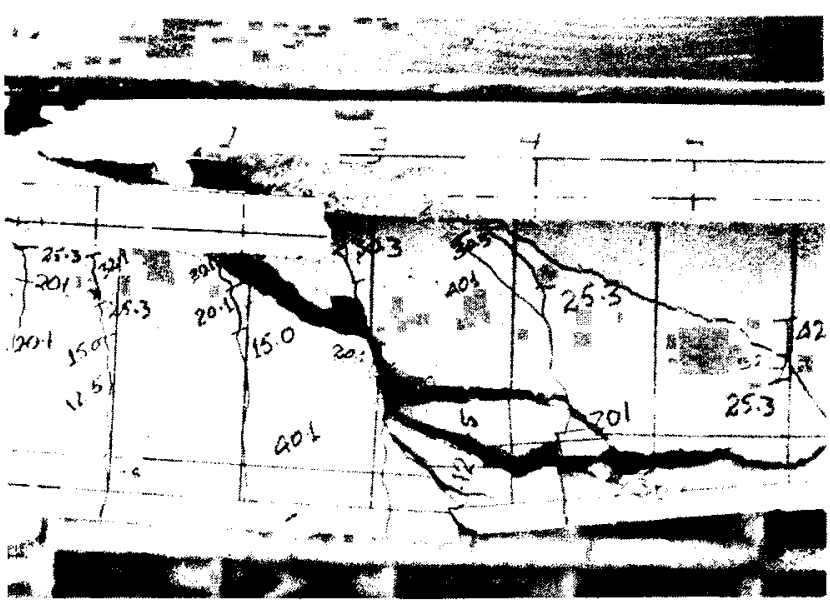

Fig. 5-Positive moment region shear failure, Beam E40

$$
\begin{gathered}
v_{c}=V_{c} / b_{w} d \\
=1.9 \sqrt{f_{c}^{\prime}}+2500 \rho_{w} V_{u} d / M_{u} \leqslant 3.5 \sqrt{f_{c}^{\prime}} \\
v_{c}=V_{c} / b_{w} d=2 \sqrt{f_{c}^{\prime}}
\end{gathered}
$$

For the beams tested in the current study, as well as those tested by Palaskas, Attiogbe, and Darwin, ${ }^{9}$ the values of $v_{c}$ obtained with Eq. (1) and (2) differ by less than 4 psi $(0.03 \mathrm{MPa})$. For the balance of this paper, comparisons will be made using Eq. (2), the less conservative (for low $\rho_{w}$ ) but more commonly used expression.

For the positive moment region, the measured shear cracking stresses are on the average 13 percent lower than predicted by $\mathrm{ACI} 318$, while for the negative moment region, the shear cracking stresses are on the average 29 percent lower than predicted by ACI 318 (Table 2).

\section{Stirrup effectiveness}

Current ACI procedures for the shear design of beams with web reinforcement have appeared to be conservative, ${ }^{9 \cdot 11}$ especially in positive moment regions. The shear force resisted by the stirrups $V_{s}$ is calculated assuming that the inclined crack has a horizontal projection equal to the effective depth of the beam $d$. For vertical stirrups, the nominal shear stress resisted by the stirrups $v_{s}$ is expressed as

$$
\mathcal{V}_{s}=V_{s} / b_{w} d=A_{v} f_{v y} / b_{w} s=\rho_{v} f_{v y}
$$

The increase in the shear stress $v_{n}-v_{c}$ above the shear cracking stress $v_{c}$ is a measure of the effectiveness of the web reinforcement and can be compared to the predicted stirrup capacity, $\rho_{v} f_{v y} . v_{n}-v_{c}$ includes the shear carried by stirrups, as well as the shear carried by dowel action and aggregate interlock. The increment of stress $v_{n}-v_{c}$ is given in Table 3 for the current study and for the beams tested by Palaskas, Attiogbe, and Darwin. ${ }^{9}$

ACI Structural Journal / January-February 1987

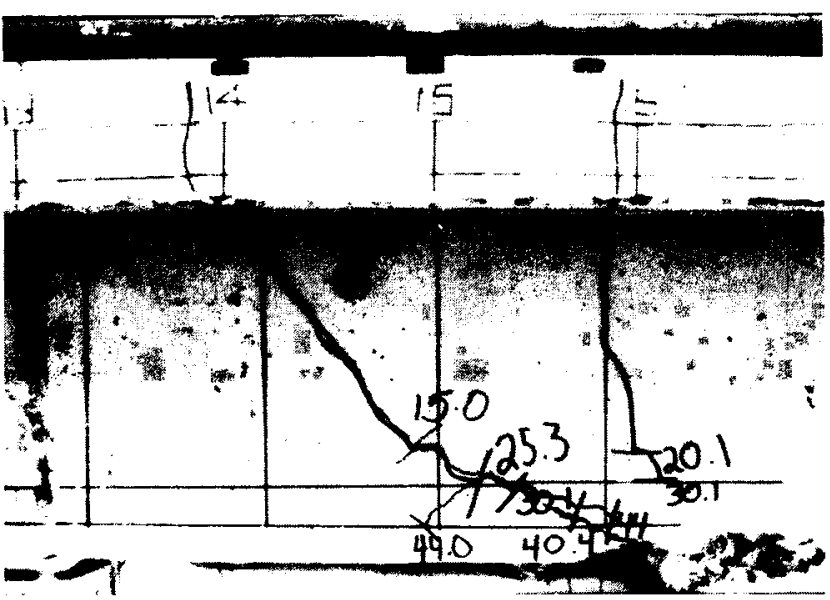

Fig. 6-Negative moment region shear failure, Beam E80

\begin{tabular}{|c|c|c|c|c|c|}
\hline \multirow[b]{2}{*}{ Beam } & \multirow[b]{2}{*}{$\begin{array}{c}\nu_{c}(\mathrm{ACI}),^{*} \\
\text { psi }\end{array}$} & \multicolumn{2}{|c|}{$\begin{array}{c}\text { Positive moment } \\
\text { region }\end{array}$} & \multicolumn{2}{|c|}{$\begin{array}{c}\text { Negative moment } \\
\text { region }\end{array}$} \\
\hline & & $\begin{array}{c}v_{c} \text { (test) } \\
\mathrm{psi}\end{array}$ & $\frac{v_{r} \text { (test) }}{v_{c}(\mathrm{ACI})}$ & $\begin{array}{c}\mathrm{v}_{\mathrm{c}} \text { (test) } \\
\mathrm{psi}\end{array}$ & $\frac{v_{c} \text { (test) }}{v_{c}(\mathrm{ACI})}$ \\
\hline $\begin{array}{l}\text { D-80(1) } \\
\text { D-80(2) } \\
\text { D-40 } \\
\text { D-20 } \\
\text { D-0 } \\
\text { E-80 } \\
\text { E-40 } \\
\text { E-20 } \\
\text { E-0 }\end{array}$ & $\begin{array}{l}146.7 \\
127.6 \\
129.6 \\
131.0 \\
134.8 \\
126.6 \\
134.9 \\
129.8 \\
134.2\end{array}$ & $\begin{array}{r}103.4 \\
138.7 \\
99.8 \\
144.9 \\
113.9 \\
113.9 \\
126.7 \\
88.7 \\
114.1\end{array}$ & $\begin{array}{l}0.70 \\
1.09 \\
0.77 \\
1.11 \\
0.84 \\
0.90 \\
0.94 \\
0.68 \\
0.85\end{array}$ & $\begin{array}{c}100.8 \\
100.0 \\
110.9 \\
111.2 \\
119.3 \\
63.7 \\
\overline{92.8} \\
67.6\end{array}$ & $\begin{array}{l}0.69 \\
0.78 \\
0.86 \\
0.84 \\
0.89 \\
0.51 \\
\overline{0} \\
0.71 \\
0.50\end{array}$ \\
\hline \multicolumn{2}{|l|}{ Mean } & & 0.87 & & 0.71 \\
\hline \multicolumn{2}{|c|}{ Standard deviation } & & 0.15 & & 0.15 \\
\hline \multicolumn{2}{|c|}{$\begin{array}{l}\text { Coefficient of } \\
\text { variation }\end{array}$} & & 17.2 & & 21.1 \\
\hline
\end{tabular}

Table 2 - Comparison of measured shear cracking stresses with values predicted by $\mathrm{ACl}$ 318-83

$v_{\mathrm{c}}=2 \sqrt{f_{\mathrm{c}}^{\prime}}$

$1000 \mathrm{psi}=6.895 \mathrm{MPa}$

Postive moment region - The test results for beams with stirrups that failed in the positive moment region, D-80(1) and E-40, are combined with the results of the lightly reinforced, simply supported T-beams tested by Palaskas, Attiogbe, and Darwin. ${ }^{9}$ The increment of shear stress $v_{n}-v_{c}$ is compared with $\rho_{v} f_{v y}$ in Fig. 7. Using a regression analysis, the following relationship is obtained

$$
\begin{aligned}
& v_{n}-v_{c}=1.59 \rho_{v} f_{v y}+1.4 \\
& \quad \text { correlation coefficient, } r=0.96
\end{aligned}
$$

Hence, the contribution of the web reinforcement in the positive moment region is on the average $1.59 \rho_{v} f_{v y}$, which is 59 percent more effective than predicted by ACI $318-83^{1}$ in Eq. (3). However, the average does not tell the whole story. For the beams tested by Palaskas, Attiogbe, and Darwin with $\rho_{w}=0.95$ percent, the contribution of web reinforcement to shear capacity matches the value of $1.8 \rho_{v} f_{v y}$ obtained by Bresler and Scordelis ${ }^{10}$ for beams with higher reinforcement ratios 


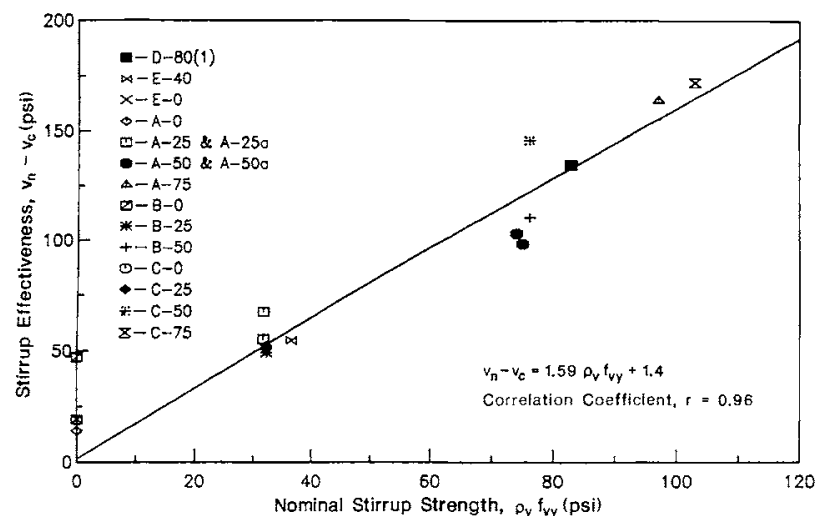

Fig. 7-Effectiveness of web reinforcement $\mathrm{v}_{\mathrm{i}}-\mathrm{v}_{\mathrm{c}}$ in positive moment regions $(1000 \mathrm{psi}=6.895 \mathrm{MPa})$

Table 3 - Stirrup effectiveness $v_{n}-v_{c}$ and comparison of measured nominal shear stresses with values predicted by $\mathrm{ACl} 318-83$

\begin{tabular}{|c|c|c|c|c|c|}
\hline Beam & $\begin{array}{c}\rho_{\mathrm{v}} f_{\mathrm{vy}}, \\
\mathrm{psi}\end{array}$ & $\begin{array}{c}v_{n}-v_{c}, \\
p s i\end{array}$ & $\begin{array}{c}v_{n} \text { (test) } \\
\text { psi }\end{array}$ & $\begin{array}{c}\mathcal{v}_{n}(\mathrm{ACI}){ }^{1} \\
\text { psi }\end{array}$ & $\frac{v_{n}(\mathrm{test})}{v_{n}(\mathrm{ACI})}$ \\
\hline \multicolumn{6}{|c|}{ Positive Moment Region } \\
\hline $\begin{array}{l}\text { D-80(1) } \\
\text { E-40 } \\
\text { E-0 } \\
\# 2^{*} \\
\text { A-00* } \\
\text { A-25* } \\
\text { A-25a* } \\
\text { A-50* } \\
\text { A-50(a) } \\
\text { A-75* } \\
\# 1^{*} \\
\text { B- } 00^{*} \\
\text { B-25* } \\
\text { B-50* } \\
\text { C-00* } \\
\text { C-25* } \\
\text { C-50* } \\
\text { C- } 75^{*}\end{array}$ & $\begin{array}{r}82.9 \\
36.8 \\
0.0 \\
0.0 \\
0.0 \\
31.8 \\
31.8 \\
74.0 \\
75.0 \\
97.0 \\
110.2 \\
0.0 \\
32.4 \\
76.2 \\
0.0 \\
32.4 \\
76.2 \\
103.0\end{array}$ & $\begin{array}{r}135 \\
55 \\
19 \\
- \\
14 \\
55 \\
68 \\
103 \\
98 \\
164 \\
- \\
47 \\
49 \\
110 \\
19 \\
52 \\
146 \\
172\end{array}$ & $\begin{array}{l}238 \\
181 \\
133 \\
147 \\
126 \\
167 \\
182 \\
225 \\
213 \\
275 \\
286 \\
136 \\
153 \\
208 \\
115 \\
166 \\
261 \\
266\end{array}$ & $\begin{array}{l}230 \\
172 \\
134 \\
138 \\
138 \\
169 \\
170 \\
198 \\
202 \\
234 \\
259 \\
136 \\
166 \\
209 \\
131 \\
161 \\
207 \\
234\end{array}$ & $\begin{array}{l}1.03 \\
1.05 \\
1.00 \\
1.10 \\
0.91 \\
0.99 \\
1.10 \\
1.14 \\
1.05 \\
1.18 \\
1.10 \\
1.00 \\
0.92 \\
1.00 \\
0.88 \\
1.03 \\
1.26 \\
1.14\end{array}$ \\
\hline \multicolumn{5}{|l|}{ Mean } & 1.04 \\
\hline \multicolumn{5}{|c|}{ Coefficient of variation } & $9.3 \%$ \\
\hline \multicolumn{5}{|c|}{ Mean (beams with stirrups) } & 1.07 \\
\hline \multicolumn{5}{|c|}{ Coefficient of variation } & $8.4 \%$ \\
\hline \multicolumn{6}{|c|}{ Negative moment region } \\
\hline $\begin{array}{l}\text { D-80(2) } \\
\text { D-40 } \\
\text { D-20 } \\
\text { D-0 } \\
\text { E-80 } \\
\text { E-20 }\end{array}$ & $\begin{array}{r}73.1 \\
37.0 \\
21.6 \\
0.0 \\
73.5 \\
22.2\end{array}$ & $\begin{array}{r}100 \\
35 \\
37 \\
18 \\
89 \\
35\end{array}$ & $\begin{array}{l}200 \\
146 \\
148 \\
138 \\
152 \\
127\end{array}$ & $\begin{array}{l}201 \\
167 \\
153 \\
135 \\
200 \\
152\end{array}$ & $\begin{array}{l}1.00 \\
0.82 \\
0.97 \\
1.02 \\
0.76 \\
0.84\end{array}$ \\
\hline \multicolumn{5}{|l|}{ Mean } & 0.91 \\
\hline \multicolumn{5}{|c|}{ Coefficient of variation } & $8.4 \%$ \\
\hline \multicolumn{5}{|c|}{ Mean (beams with stirrups) } & 0.89 \\
\hline \multicolumn{5}{|c|}{ Coefficient of variation } & $11.0 \%$ \\
\hline
\end{tabular}

$\left(\rho_{w}=1.8\right.$ percent and 2.4 percent $)$. Haddadin, Hong, and Mattock ${ }^{11}$ found the contribution for beams with $\rho_{w}$ $=3.8$ percent to be at least $1.75 \rho_{v} f_{v y}$ for values of $\rho_{i} f_{v y}$ less than $200 \mathrm{psi}$. For the beams with $\rho_{w}=0.50$ percent and 0.70 percent the stirrup contribution is noticeably lower, at about $1.4 \rho_{v} f_{v y}$ for both values of $\rho_{w}$.

82

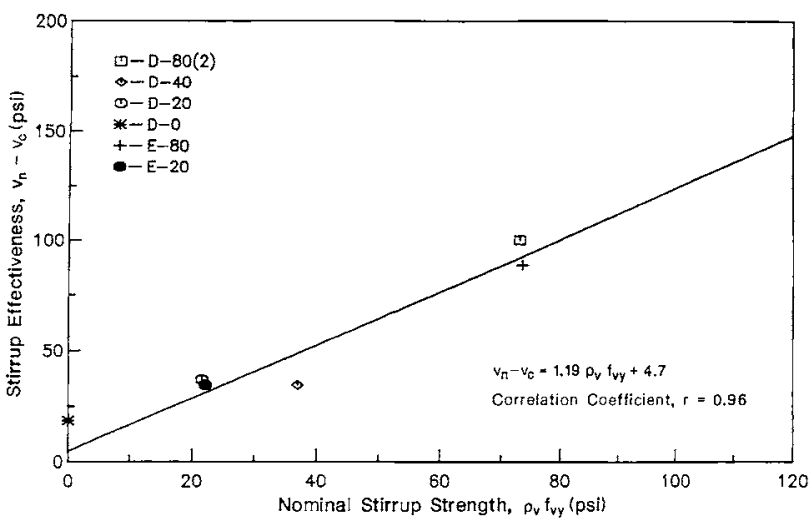

Fig. 8-Effectiveness of web reinforcement $v_{\mathrm{n}}-\mathrm{v}_{\mathrm{c}}$ in negative moment regions ( $1000 \mathrm{psi}=6.895 \mathrm{MPa})$

Negative moment region $-v_{n}-v_{c}$ is compared to $\rho_{1} f_{i y}$ in the negative moment region in Fig. 8. Using a regression analysis, the following equation is obtained

$$
\begin{aligned}
v_{n}-v_{c} & =1.19 \rho_{v} f_{v y}+4.70 \\
& \text { correlation coefficient, } r,=0.96
\end{aligned}
$$

On the average, the web reinforcement in the negative moment region is only 1.19 times as effective as predicted by Eq. (3), compared to about 1.4 for the beams with similar reinforcement ratios in the positive moment region.

Although Haddadin, Hong, and Mattock" had only limited data in the negative moment region, they also obtained a lower stirrup contribution to shear strength in the negative moment region than in the positive moment region at values of $\rho_{v} f_{v y}$ below $200 \mathrm{psi}(1.4 \mathrm{MPa})$.

\section{Horizontal crack projection}

An explanation for the lower stirrup effectiveness in negative moment regions can be obtained by studying the horizontal crack projections. The horizontal projections of the critical shear cracks are noticeably greater for the beams which failed in positive moment regions than for the beams that failed in negative moment regions. In positive moment regions, horizontal projections averaged $1.7 d$, ranging from 1.4 to $2.2 d$, and while in the negative moment regions, they average $1.0 d$, ranging from 0.9 to $1.1 d$, with the exception of one beam, E-20, with a horizontal crack projection of 1.4d (Fig. 4).

Due to the longer horizontal crack projection in the positive moment region, the number of stirrups intercepted by the critical crack is larger. Hence, the shear taken by the stirrups is larger, explaining why $v_{n}-v_{c}$ is greater in the positive moment region.

The more heavily reinforced beams tested by Haddadin, Hong, and Mattock ${ }^{11}$ also exhibited greater horizontal projections of critical shear cracks in positive moment regions ( 1.9 to $2.3 d$ ) than in negative moment regions $(1.5$ to $1.7 d)$. These projections are on the average longer in both regions than obtained for the more lightly reinforced beams in this study.

ACI Structural Journal / January-February 1987 


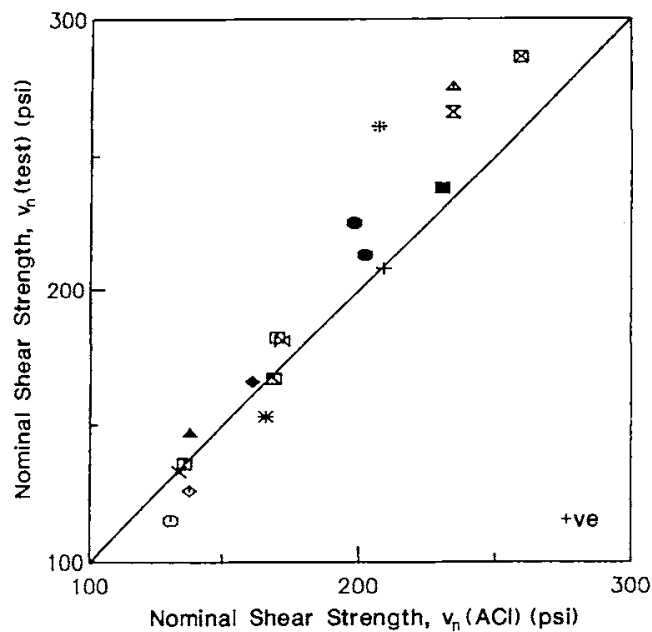

(a)

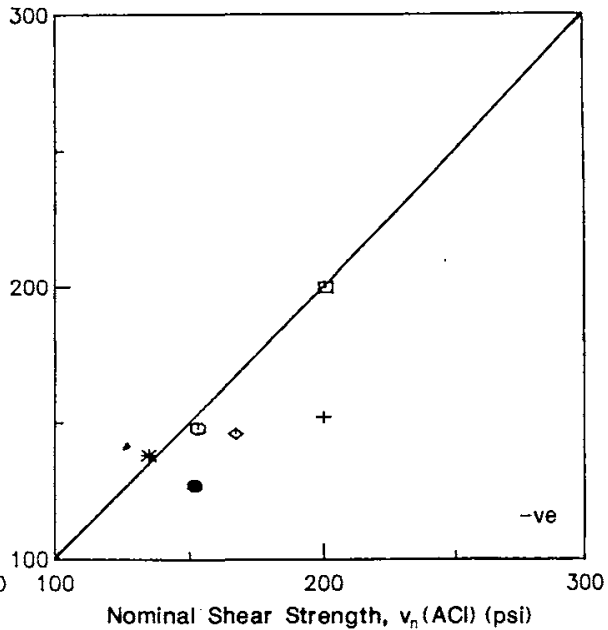

(b)

Fig. 9-Comparison of predicted and experimental nominal shear stresses: (a) positive moment region, and $(b)$ negative moment region $(1000 \mathrm{psi}=6.895 \mathrm{MPa})$

\section{Nominal shear stress}

The measured nominal shear stresses are compared with the nominal shear stresses predicted by ACI 318 $83^{\prime}$ in Table 3 and Fig. 9 for the current series, as well as the 15 lightly reinforced beams tested by Palaskas, Attiogbe, and Darwin. ${ }^{9}$

For beams that failed in the positive moment regions, the ACI 318 provisions are conservative for 12 out of the 18 beams, both with and without stirrups. The average value of $v_{n}$ (test) $/ v_{n}$ (ACI) in these 18 beams is 1.04 , with extreme values of 1.26 and 0.88 , and a coefficient of variation of 9.3 percent. The ACI provisions are conservative for 11 out of the 14 beams with stirrups that failed in the positive moment region. The average value of $v_{n}$ (test) $/ v_{n}$ (ACI) for beams with stirrups is 1.07 , with extreme values of 1.26 and 0.99 , and a coefficient of variation of 8.4 percent.

For beams that failed in the negative moment region, the $\mathrm{ACl}$ provisions are unconservative for four out of the six beams, both with and without stirrups. The average value of $v_{n}$ (test) $/ v_{n}$ (ACI) in these six beams is 0.91 , with extreme values of 1.02 and 0.76 , and a coefficient of variation of 8.4 percent. The ACI provisions are unconservative for four out of five beams with stirrups that failed in the negative moment region. The average value of $v_{n}$ (test) $/ v_{n}$ (ACI) for the beams with stirrups is 0.89 , with extreme values of 1.0 and 0.76 , and a coefficient of variation of 11.0 percent.

On average, the nominal shear strength is 14.3 percent greater in the positive moment regions than in the negative moment regions. For beams with stirrups, the nominal shear strength is 20.2 percent greater in positive moment regions than in negative moment regions.

In the positive moment regions, the relatively small drop in the concrete contribution due to the low value of $\rho_{w}$, combined with the higher stirrup contribution to shear strength, makes $\mathrm{ACI} 318^{\prime}$ conservative for nominal shear strength. Therefore, in positive moment regions, even though the concrete contribution to shear

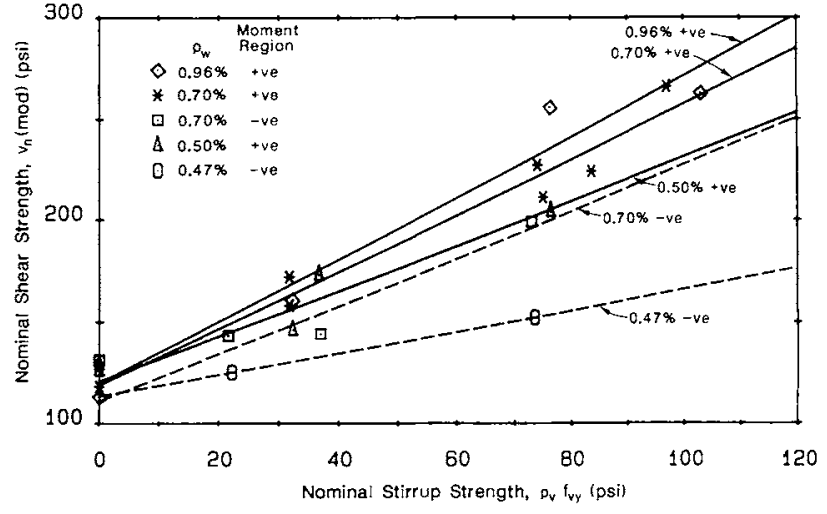

Fig. 10-Modified nominal shear stress $\mathrm{v}_{\mathrm{n}}($ mod) versus $\rho_{\imath} f_{v y}(1000 p s i=6.895 \mathrm{MPa})$

strength is less than predicted by Eq. (1) and (2), this is more than compensated by the higher effectiveness of the stirrups.

However, in negative moment regions, although the stirrup contribution averages $1.19 \rho_{v} f_{v y}$, it is not high enough to adequately compensate for the low concrete contribution to shear strength. Therefore, for low values of $\rho_{w}$, the nominal shear strength remains less than predicted by ACI 318.

\section{SAFETY OF CURRENT PROVISIONS}

The major question that must be answered is: When are the current provisions safe, and when are they unsafe? The answer can be obtained by considering the combined effects of flexural reinforcement, moment region, and shear reinforcement.

In Fig. $10, \mathrm{v}_{\mathrm{n}}$ is plotted versus $\rho_{\mathrm{g}} f_{\mathrm{ry}}$ for each value of $\rho_{w}$ and moment region. In this figure, $v_{n}$ is modified to an equivalent strength, in terms of $4000 \mathrm{psi}(27.6 \mathrm{MPa})$ concrete, in order to help eliminate the effect of variations in concrete strength 


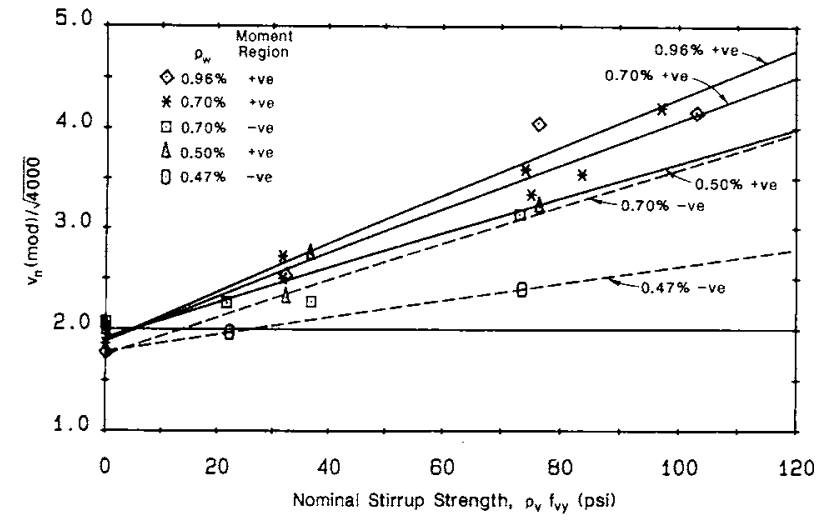

Fig. II-Nominal shear stress normalized to concrete strength, $v_{\mathrm{n}}(\mathrm{mod}) / \sqrt{4000}$, versus $\rho_{\mathrm{v}} \mathrm{f}_{\mathrm{v}}(1000 \mathrm{psi}=6.895$ $M P a)$

$$
\begin{aligned}
v_{n}(\bmod ) & =v_{c}(\text { test })\left(\sqrt{4000 / f_{c}^{\prime}}\right) \\
& +\left[v_{n} \text { (test) }-v_{c} \text { (test) }\right]
\end{aligned}
$$

The lines are least-square fits of the data.

Fig. 10 illustrates that the nominal shear stress $v_{n}$ and the stirrup effectiveness (slope of the lines) increase with $\rho_{w}$ and that $v_{n}$ and stirrup effectiveness are higher in positive moment regions than in negative moment regions.

The shear provisions in ACI $318^{1}$ must be evaluated at two levels of factored load $V_{u}$ : (1) values of $V_{u} \leqslant$ $\phi V_{c}$, where minimum stirrups may be required, but need not be designed; and (2) values of $V_{u}>\phi V_{c}$, where the stirrups must be designed, i.e., $\phi V_{s} \geqslant V_{u}-$ $\phi V_{c}$.

$V_{u} \leqslant \phi V_{c}$-For values of $V_{u} \leqslant \phi V_{c} / 2$, no stirrups are required by ACI 318.' Lightly reinforced beams are safe at low values of $V_{u}$, since all tests indicate that the shear cracking stress $v_{c}$ is in excess of $\sqrt{f_{c}^{\prime}} \cdot{ }^{4,8,9,13}$

For $\phi V / 2<V_{u} \leqslant \phi V_{c}$, ACI $318^{\mathrm{l}}$ requires minimum stirrups, except for joists and slabs.

Fig. 11 compares $v_{n}(\bmod ) / \sqrt{4000}$ versus $\rho_{1} f_{y y}$ to evaluate the safety of beams for which minimum shear reinforcement $\left(\rho_{v} f_{v y}=50 \mathrm{psi}[0.34 \mathrm{MPa}]\right)$ is required. To insure safety, $v_{n}$ (mod) must equal or exceed the code value of $v_{c}=2 \sqrt{f_{c}^{t}}$ for beams with $\rho_{v} f_{v y} \geqslant 50$ psi $(0.34$ $\mathrm{MPa}$ ) (i.e., $\mathrm{v}_{\mathrm{n}}$ (mod) $/ \sqrt{4000}$ must exceed 2).

Fig. 11 illustrates that, in all cases, the use of the minimum web reinforcement allows the beams to develop a nominal shear stress $v_{n}$ in excess of $2 \sqrt{f_{c}^{\prime}}$. As little as 25 psi $(0.17 \mathrm{MPa})$ of web steel appears to be sufficient to raise $v_{n}$ to $2 \sqrt{f_{c}^{\prime}}$ for beams with $\rho_{w^{\prime}} \geqslant 0.5$ percent, even in the negative moment region. Hence, if the minimum web reinforcement is used, the nominal shear capacity predicted by ACI $318, V_{n}=V_{c}$, is safe.

It is important to note that since joists are exempt from the minimum web reinforcement requirements,' they represent a widely used class of lightly reinforced member that may be unsafe.

$V_{u}>\phi V_{c}$-For $V_{u}>\phi V_{c}$, shear reinforcement is required. In this case, it is necessary to establish the ranges of $\rho_{w}$ and $\rho_{v} f_{i, y}$ over which the current provisions

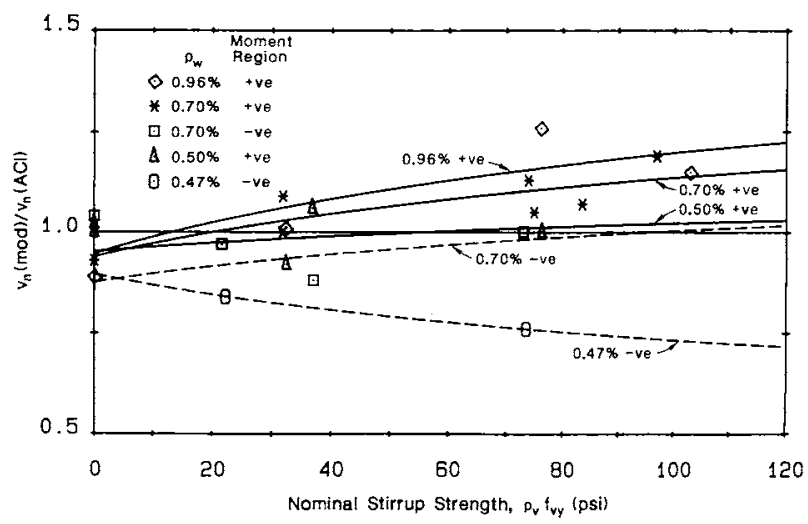

Fig. 12-Nominal shear stress normalized to predicted nominal shear stress, $\mathrm{v}_{\mathrm{n}}(\bmod ) / \mathrm{v}_{\mathrm{v}}(A C I)$, versus $\rho_{\mathrm{v}} \mathrm{f}_{\mathrm{vy}}$ $(1000 \mathrm{psi}=6.895 \mathrm{MPa})$

are conservative. This can be done by normalizing the modified data illustrated in Fig. 10 to the predicted nominal shear stress, $v_{n}(\mathrm{ACI})=2 \sqrt{f_{c}^{\prime}}+\rho_{\mathrm{l}} f_{\mathrm{l} y}$. Fig. 12 shows that for positive moment regions, $v_{n}$ is greater than $v_{n}(\mathrm{ACI})$ if $\rho_{r} f_{i, y}$ is greater than $50 \mathrm{psi}$. The shear capacity is actually about 0.3 percent less than predicted for beams with $\rho_{i,}=0.5$ percent and $\rho_{\mathrm{v}} f_{\mathrm{r}, \mathrm{y}}=50$ psi (0.34 MPa).

However, for negative moment regions, $v_{n}$ is lower than $v_{n}(\mathrm{ACI})$, even for values of $\rho_{v} f_{v y}$ much greater than 50 psi (0.34 MPa). For $\rho_{y} f_{v y}=50$ psi $(0.34 \mathrm{MPa})$, the shear capacity is 5 and 21 percent less than predicted by ACI $318^{\prime}$ for beams with $\rho_{w}=0.7$ and 0.47 percent, respectively. For $\rho_{w}=0.7$ percent, $v_{n}$ only equals $v_{n}(\mathrm{ACI})$ for values of $\rho_{v} f_{v y}$ greater than 95 psi $(0.66 \mathrm{MPa})$. For $\rho_{w}=0.47$ percent, the limited data suggests that $v_{n}$ will not reach $v_{n}$ (ACI) for any value of $\rho_{v} f_{v y}$.

Hence, while the minimum shear reinforcement provisions remain satisfactory, the safety of beams in negative moment regions with low amounts of flexural reinforcement is in doubt, if the strength of the stirrups is used to compute shear capacity. In this case, the minimum web reinforcement $\left(\rho_{v} f_{v y}=50\right.$ psi $[0.34$ $\mathrm{MPa}]$ ) will clearly not provide the predicted nominal shear capacity $V_{n}$.

\section{CONCLUSIONS}

The following conclusions are based on the test results and evaluation of the lightly reinforced $T$-beams described in this paper.

1. For the same longitudinal reinforcement ratio $\rho_{w}$, diagonal cracks form at a higher shear stress in positive moment regions than in negative moment regions of reinforced concrete $\mathrm{T}$-beams. This lower relative negative moment region shear strength appears to be the result of a smaller effective concrete section due to cracking of the flanges, and a lower bond strength for the negative longitudinal reinforcement, due to the topbar effect.

2. In both moment regions, the cracking shear is lower than predicted by ACI 318 .

ACI Structural Journal / January-February 1987 
3. Negative moment regions exhibit fewer cracks at a wider spacing than positive moment regions, also due to the top bar effect.

4. For lower values of shear reinforcement (up to about 200 psi [1.4 MPa]), the stirrup contribution to shear strength is greater in positive moment regions than in negative moment regions. This appears to be largely due to a greater horizontal crack projection, which results in a greater number of stirrups intersected by the critical shear crack.

5. In both moment regions, the stirrup contribution exceeds that predicted by ACI $318 .{ }^{1}$

6. The current shear provisions in $\mathrm{ACI} 318^{\prime}$ appear to be conservative for the positive moment regions of beams with $\rho_{w} \leqslant 0.5$ percent.

7. The shear provisions ${ }^{1}$ are also conservative for the negative moment regions of beams in which $V_{u} \leqslant \phi V_{i}$.

8. However, the shear provisions appear to be unconservative for the negative moment regions of beams with $\rho_{w} \leqslant 0.70$ percent and $V_{u}>\phi V_{i}$.

9. The shear provisions may also be unconservative for joists with $\rho_{w} \leqslant 1.0$ percent and $\phi V_{c} / 2 \leqslant V_{u} \leqslant$ $\phi V_{c}$, since these members are not covered by the minimum web reinforcement provisions of ACI 318.

\section{FUTURE WORK}

The current test series represents the only existing data for the negative moment region shear strength of beams with low values of both flexural and shear reinforcement. Clearly, the data is too limited to enable design provisions to be modified in a rational manner to account for the low shear strength of these members. Additional tests are needed, with a broader range of test variables.

These tests should include true continuous beams with different shear-span-to-depth ratios, concrete strengths, reinforcement ratios, mild reinforcement and perhaps deformed bars for stirrups. Reinforced concrete joist construction deserves special consideration, since it is currently exempt from the minimum shear reinforcement provisions and enjoys a 10 percent increase in the value of $V_{i .}{ }^{\prime}$ Finally, the effect of reinforcement ratio on the shear capacity of beams in which longitudinal reinforcement is terminated remains a completely open question.

\section{ACKNOWLEDGMENTS}

This research was performed at the University of Kansas Structural Engineering and Materials Laboratory. Support was provided by the National Science Foundation under NSF Grant No. PFR 7924696. Sheffield Steel Corporation and ARMCO, Inc., respectively, donated the deformed bars and wire reinforcing steel.

\section{REFERENCES}

1. ACl Committee 318, "Building Code Requirements for Reinforced Concrete (ACI 318-83)," American Concrete Institute, Detroit, $1983,111 \mathrm{pp}$.

2. Krefeld, William J., and Thurston, Charles W., "Studies of the Shear and Diagonal Tension Strength of Simply Supported Reinforced Concrete Beams," Report, Columbia University, New York, June $1962,96 \mathrm{pp}$.

3. Kani, G. N. J., "Basic Facts Concerning Shear Failure," ACl Journal, Proceedings V. 63, No. 6, June 1966, pp. 675-692.

4. Rajagopalan, K. S., and Ferguson, Phil M., "Exploratory Shear Tests Emphasizing Percentage of Longitudinal Steel," ACI JourNAL, Proceedings V. 65, No. 8, Aug. 1968, pp. 634-638.

5. Zsutty, Theodore C., "Beam Shear Strength Prediction by Analysis of Existing Data," ACI Journal, Proceedings V. 65, No. 11, Nov. 1968, pp. 943-951.

6. Placas, Alexander, and Regan, Paul E., "Shear Failure of Reinforced Concrete Beams," ACl Journal, Proceedings V. 68, No. 10, Oct. 1971, pp. 763-773.

7. Rangan, B. V., "A Comparison of Code Requirements for Shear Strength of Reinforced Concrete Beams," Shear in Reinforced Concrete, SP-42, American Concrete Institute, Detroit, 1974, pp. 285-303.

8. Batchelor, Barrington deV., and Kwun, Mankit, "Shear in RC Beams without Web Reinforcement," Proceedings, ASCE, V. 107, ST5, May 1981, pp. 907-921.

9. Palaskas, Michael N.; Attiogbe, Emmanuel K.; and Darwin, David, "Shear Strength of Lightly Reinforced T-Beams," ACI Journal, Proceedings V. 78, No. 6, Nov.-Dec. 1981, pp. 447-455.

10. Bresler, Boris, and Scordelis, A. C., "Shear Strength of Reinforced Concrete Beams," ACI Journal, Proceedings V. 60, No. 1, Jan. 1963, pp. $51-72$.

11. Haddadin, Munther J.; Hong, Sheu-Tien; and Mattock, Alan H., "Stirrup Effectiveness in Reinforced Concrete Beams with Axial Force," Proceedings, ASCE, V. 97, ST9, Sept. 1971, pp. 2227-2297.

12. Ferguson, Phil M., Reinforced Concrete Fundamentals, 4th Edition; John Wiley \& Sons, New York, 1979, 724 pp.

13. Rodrigues, Carlos P., and Darwin, David, "Negative Moment Region Shear Strength of Lightly Reinforced T-Beams," SM Report No. 13, University of Kansas Center for Research, Lawrence, June 1984, $111 \mathrm{pp}$. 